\title{
Deposition of cellular fibronectin and desorption of human serum albumin during adhesion and spreading of human endothelial cells on polymers
}

\author{
A. DEKKER, T. BEUGELING, H. WIND, A. POOT, A. BANTJES, J. FEIJEN, \\ W. G. van AKEN \\ Faculty of Chemical Technology, University of Twente, P.O. Box 217, 7500 AE Enschede, \\ The Netherlands
}

More insight into the mechanism of adhesion of human endothelial cells (HEC) on to polymeric surfaces may lead to the development of improved small-diameter vascular grafts. HEC suspended in $20 \%$ human serum-containing culture medium adhere and spread well on moderately water-wettable polymers such as tissue culture polystyrene (TCPS). Earlier it was demonstrated that during adhesion and spreading of HEC on TCPS, cellular fibronectin is deposited on to this surface. It was postulated that fibronectin deposition is accompanied by desorption of adsorbed serum proteins, e.g. human serum albumin (HSA). The amounts of adsorbed (cellular) fibronectin and HSA on TCPS surfaces pretreated for $1 \mathrm{~h}$ with solutions of human serum (ranging from $0.01 \%-20 \%$ ), were determined after incubation of these surfaces for $6 \mathrm{~h}$ with HEC in culture medium and after incubation with culture medium without cells. Protein adsorption was determined by means of a two-step enzyme-immunoassay (EIA). HEC adhesion and spreading on TCPS resulted in a significant deposition of fibronectin irrespective of the serum concentration in the solution used for the pretreatment of TCPS. The deposition of cellular fibronectin on to TCPS, pretreated with human serum, was accompanied by displacement of adsorbed HSA. Desorption of HSA from TCPS was only detectable with the EIA at serum concentrations ranging from $0.01 \%-1 \%$. Using ${ }^{131}-1$-labelled HSA as tracer protein; it could, however, be demonstrated that HSA was also displaced from TCPS, pretreated with solutions of higher serum concentrations. Pretreatment of the hydrophobic vascular graft material PET (poly (ethylene terephthalate); Dacron) and of FEP (fluoroethylenepropylene copolymer; a Teflon-like polymer) with a solution containing $20 \%$ human serum resulted in a reduced adhesion of HEC compared to uncoated surfaces. We suggest that this may be caused by a poor displacement of adsorbed serum proteins from these hydrophobic surfaces by cellular fibronectin. This may explain why HEC normally fail to adhere on to prosthetic surfaces.

\section{Introduction}

The clinical results with small diameter $(<5 \mathrm{~mm})$ vascular grafts are, in general, disappointing, predominantly because of thrombotic occlusion [1-3]. Because vascular endothelium represents a unique, non-thrombogenic surface, endothelial cells are the logical choice for lining a prosthesis. [4]. Endothelial lining leads to improved patency of prostheses while reduced platelet deposition is observed on the luminal surface, both in humans and dogs [5-7]. However, in humans, prostheses are not spontaneously overgrown by endothelial cells $[2,8,9]$. Seeding of prostheses with (autologous) endothelial cells may be a method to cover the luminal surface with cells, provided that adhesion of endothelial cells on to polymeric surfaces is optimal.
In order to optimize the interaction of endothelial cells with polymers, more insight is required into the mechanism of adhesion, spreading and proliferation of endothelial cells on polymeric surfaces. From in vitro data it is known that human endothelial cells, suspended in $20 \%$ human serum-containing culture medium, only adhere and proliferate well on polymeric surfaces which are moderately water-wettable (e.g. tissue culture polystyrene; TCPS) [3]. Protein adsorption from serum-containing culture medium to a polymeric surface will occur almost instantaneously. Therefore, protein adsorption is one of the major determinants for adhesion and spreading of cells on polymers. Research on protein adsorption in our laboratory revealed that the amount of adsorbed fibronectin, a protein which promotes cell adhesion, 
from culture medium containing $20 \%$ human serum to TCPS is relatively small [10]. However, from this culture medium, relatively large amounts of highdensity lipoprotein, immunoglobulin $\mathrm{G}$ and human serum albumin (HSA), which all inhibit cell adhesion, adsorb to TCPS. In spite of the high adsorption of these proteins, endothelial cells adhere and spread well on TCPS $[3,10]$. Moreover, endothelial cell-derived fibronectin is deposited in relatively large amounts on to TCPS during adhesion and spreading $[11,12]$. Proteins generally adsorb to surfaces as a monolayer of molecules, but do not adsorb to already adsorbed protein molecules $[13,14]$. Therefore, we postulate that during adhesion and spreading of human endothelial cells on TCPS, adsorbed serum proteins are displaced by cellular fibronectin. This hypothesis may have consequences for adhesion and spreading of endothelial cells on surfaces other than TCPS. Most probably the displacement of proteins will occur more easily from relatively hydrophilic surfaces than from hydrophobic surfaces, because less reversible protein adsorption to the latter type of surfaces occurs $[15$, $16]$. We assume that this is the reason why endothelial cells adhere and spread well on TCPS and do not adhere and spread on more hydrophobic surfaces.

In order to test the hypothesis with respect to the displacement of adsorbed proteins by cellular fibronectin, the adsorption of fibronectin and human serum albumin to TCPS, pretreated with solutions of various concentrations of human serum, was studied after incubation of these surfaces with endothelial cells in a culture medium and after incubation with a medium without cells. Moreover, adhesion of human endothelial cells on to other polymers which were pretreated with solutions of $20 \%$ human serum, or which were not pretreated, was studied. These polymers differed in wettability.

\section{Materials and methods}

\subsection{Polymers}

The polymers used in this study were: tissue culture polystyrene (TCPS); poly(ethylene terephthalate) (PET, Melinex polyester, type 0), tissue culture poly(ethylene terephthalate) (TCPET, Falcon filmlined dish), and fluoroethylenepropylene copolymer (FEP; film type $500 \mathrm{~A}$ ). TCPS and TCPET, in the form of tissue culture clusters or dishes, were used asreceived from the manufacturer. PET and FEP were cleaned ultrasonically for $30 \mathrm{~min}$ in $1 \%(\mathrm{vol} / \mathrm{vol})$ detergent solution (RBS 25) and extensively rinsed with distilled water and absolute ethanol (pro analysi). For both protein-adsorption and cell-adhesion experiments, sheets of PET, TCPET and FEP were mounted in a test device as described by Poot et al. [17]. Each well of this device has a surface area of $0.8 \mathrm{~cm}^{2}$. TCPS was used as 24-well clusters $\left(2 \mathrm{~cm}^{2}\right.$ per well), except for experiments in which radio-iodinated HSA was used. In these experiments TCPS 48-well clusters $\left(1 \mathrm{~cm}^{2}\right.$ per well) were applied.

\subsection{Protein coating}

Polymer surfaces were exposed for $1 \mathrm{~h}$ at room tem- perature to solutions with the following concentrations of human serum: $20 \%, 10 \%, 1 \%, 0.1 \%, 0.05 \%$ and $0.01 \%(\mathrm{vol} / \mathrm{vol})$. Human serum was diluted to a concentration of $20 \%$ with serum-free culture medium (see Section 2.3). Solutions with the other concentrations of human serum were made by diluting this serum-containing culture medium with phosphatebuffered saline (PBS; $8.2 \mathrm{~g} / 1 \mathrm{NaCl}, 3.1 \mathrm{~g} / 1 \mathrm{Na}_{2} \mathrm{HPO}_{4}$. $12 \mathrm{H}_{2} \mathrm{O}, 0.2 \mathrm{~g} / 1 \quad \mathrm{NaH}_{2} \mathrm{PO}_{4} \cdot 2 \mathrm{H}_{2} \mathrm{O} ; \mathrm{pH}$ 7.4). After incubation, the wells were rinsed three times with PBS.

\subsection{Cell culture}

Human endothelial cells were isolated from umbilical cord veins using Willems et al.'s method [18]. The cells were routinely cultured, as described by Van Wachem et al. [19], in tissue culture polystyrene flasks precoated with partially purified fibronectin (co-product obtained during the preparation of human factor VIII concentrate from cryoprecipitate). The culture medium consisted of a 1:1 mixture of Medium 199 and RPMI 1640, containing $20 \%$ pooled human serum derived from 20 healthy male donors, $2 \mathrm{~mm}$ $L$-glutamine, $100 \mathrm{U} \mathrm{ml}^{-1}$ penicillin, $100 \mu \mathrm{g} \mathrm{ml}^{-1}$ streptomycin and $4 \mu \mathrm{g} \mathrm{ml}^{-1}$ fungizone.

\subsection{Cell seeding and lysis}

Cells were harvested from confluent cultures after the second or third passage by treatment with trypsin $(0.05 \%$ trypsin $/ 0.02 \%$ EDTA). Trypsin was inhibited by adding $20 \%$ serum-containing culture medium. In order to study the deposition of fibronectin as a function of time, cells were suspended in $20 \%$ serumcontaining culture medium and seeded into wells at a density of $60000 \mathrm{cells}^{-2}$. In all other experiments cells were washed three times with serum-free culture medium (the previously defined medium lacking serum) and seeded at a density of 200000 cells cm $\mathrm{cm}^{-2}$. After the appropriate incubation time, non-adherent cells were removed by rinsing with PBS. In order to make the adsorbed proteins beneath the adherent cell layer accessible to antibodies, a method previously described by Van Wachem et al. [11], was used to remove the adherent cells. These cells were lysed with $0.1 \mathrm{~N}$ ammonia for $10 \mathrm{~min}$, followed by rinsing three times with PBS. The exposed protein layer was fixed for $15 \mathrm{~min}$ with absolute methanol (pro analysi) and rinsed again with PBS. The wells, filled with PBS, were stored at $4{ }^{\circ} \mathrm{C}$ before determination of the amounts of adsorbed proteins.

\subsection{Determination of the amounts of adsorbed proteins}

The relative amounts of adsorbed proteins were determined either by means of a two-step enzyme-immunoassay or by the use of radio-iodinated human serum albumin as tracer protein added to the serum-containing culture medium.

The two-step enzyme-immunoassay was carried out as described by Van Wachem et al. [10]. This assay was performed in the following way. Subsequently, surfaces with adsorbed proteins were rinsed four times 
with PBS supplemented with Tween-20 $(0.005 \%$; $\mathrm{wt} / \mathrm{vol})$ and incubated for $1 \mathrm{~h}$ with $400 \mu \mathrm{l}$ solution of the first antibody, either directed against human fibronectin or human serum albumin (CLB). These antiserums were diluted 100 times with antibody buffer $(150 \mathrm{~mm} \mathrm{NaCl}, 50 \mathrm{~mm}$ tris-HCl; $0.2 \%$ (wt/vol) gelatin, $0.02 \%$ (wt/vol) Tween-20), supplemented with $0.5 \%(\mathrm{wt} / \mathrm{vol})$ bovine serum albumin. Wells were rinsed four times with PBS/Tween-20 and incubated for $1 \mathrm{~h}$ with $400 \mu \mathrm{l}$ enzyme-labelled second antibody solution (horse-radish peroxidase conjugated sheepanti-rabbit IgG). This peroxidase-labelled antibody was first diluted 200 times with the unlabelled equivalent (CLB) and subsequently diluted 1000 times with the previously defined antibody buffer containing $5 \%$ instead of $0.5 \%$ bovine serum albumin. After rinsing with PBS/Tween-20, the wells were incubated in the dark for 30 min with $400 \mu l$ leuko dye solution containing hydrogen peroxide. The leuko dye solution consisted of $165 \mu 1 \quad 3,3^{\prime}, 5,5^{\prime}$-tetramethylbenzidine $(6 \mathrm{mg} / \mathrm{ml} \mathrm{DMSO})$ and $10 \mathrm{ml} 0.11 \mathrm{~m}$ sodium acetate/ citric acid, $\mathrm{pH}$ 5.5. Just before use, $10 \mu \mathrm{l} 3 \% \mathrm{H}_{2} \mathrm{O}_{2}$ solution (enzyme substrate) was added to the leuko dye solution. The enzymatic colour reaction was stopped by adding $200 \mu \mathrm{l} 4 \mathrm{~N} \mathrm{H}_{2} \mathrm{SO}_{4}$. Part of the dye solution from each well $(250 \mu \mathrm{l})$ was transferred into wells of a 96-well plate and the absorbance was measured at $450 \mathrm{~nm}$ using a multiscanner. The dye solution was diluted before measurement, when the absorbance exceeded the value of 2.0 . When protein adsorption on to sheets of FEP, PET and TCPET, which were mounted in the test device (see Section 2.2), was measured, half of the mentioned amounts of antibody solutions, leuko dye solutions and sulphuric acid were used. The data, presented as protein adsorption, are the mean values of absorbance measurements of dye solutions obtained from wells of a test device or tissue culture cluster. In each protein displacement experiment in which TCPS was exposed to a particular serum concentration, the amount of HSA adsorbed after incubation with medium without cells, was taken as $100 \%$. The amount of adsorbed fibronectin after incubation with medium containing cells was taken as $100 \%$.

Experiments with radio-iodinated human serum albumin as tracer protein were performed in the following way: to $20 \%$ human serum-containing culture medium, ${ }^{131}$ I-labelled human serum albumin was added to a final concentration of $0.012 \mathrm{mg} \mathrm{ml}^{-1}$. The amount of added HSA was $0.12 \%(\mathrm{wt} / \mathrm{wt})$ of the native HSA present in the $20 \%$ serum-containing culture medium. Part of this culture medium was diluted with PBS to $1 \%$ human serum. TCPS wells, excised from a 48-well cluster, were coated with these solutions as described above. After incubation for $6 \mathrm{~h}$ with serumfree culture medium either with or without cells, the wells were rinsed with serum-free medium. Subsequently the radioactivity of each well was counted with a LKB compugamma $1282 \gamma$-counter.

\subsection{Cell adhesion}

Cell adhesion on to TCPS, TCPET, PET and FEP, either pre-exposed to $20 \%$ human serum-containing culture medium or not pre-exposed to this medium, was determined after incubation for $6 \mathrm{~h}$ with a cell suspension. Non-adherent cells were removed by rinsing with PBS and the number of adherent cells was determined by measuring the amount of DNA using Hoechst dye 33258 enhanced fluorescence of DNA. A combination of the methods of West et al. [20] and Mates et al. [21] was used. In order to release the DNA from the cells, the wells were incubated with $0.70 \mathrm{ml} 10 \mathrm{~mm}$ EDTA (pH 12.3) for $10 \mathrm{~min}$. From this solution, $0.65 \mathrm{ml}$ was taken and mixed with $0.75 \mathrm{ml}$ $10 \mathrm{~mm}$ EDTA (pH 12.3) and $0.110 \mathrm{ml} 1 \mathrm{M} \mathrm{KH}_{2} \mathrm{PO}_{4}$ to reach $\mathrm{pH} 7.0$. To this solution, $1.5 \mathrm{ml}$ Hoechst 33258 ( $800 \mathrm{ng} \mathrm{ml}^{-1} ; 100 \mathrm{~mm} \mathrm{NaCl}, 10 \mathrm{~mm}$ tris- $\mathrm{HCl}, \mathrm{pH} 7.0$ ) was added just before measuring the fluorescence with a Perkin-Elmer LS 3 fluorescence spectrometer using excitation and emission wavelengths of 360 and $450 \mathrm{~nm}$, respectively. Cell adhesion is expressed as the percentage of the number of adherent cells on TCPS coated with partially purified fibronectin (reference surface).

\section{Results}

\subsection{Amounts of adsorbed HSA and fibronectin}

In order to study the mechanism of endothelial cell adhesion on to TCPS, cells suspended in serum-free medium were seeded into TCPS wells pre-exposed to solutions with different concentrations of human serum. The relative amounts of fibronectin and HSA adsorbed to TCPS after $6 \mathrm{~h}$ incubation of these coated wells with either serum-free medium or with a suspension of endothelial cells in serum-free medium is shown in the graphs of Fig. 1. These graphs reveal that, irrespective of the serum concentration in the coating solution, the amount of adsorbed fibronectin is significantly higher when the surfaces had been exposed to endothelial cells in serum-free medium compared to surfaces incubated with serum-free medium without cells. The amounts of HSA present on these TCPS surfaces were also determined. In general, it was found that after incubation with a suspension of endothelial cells, less adsorbed HSA was present on TCPS than after incubation with serumfree medium without cells. This decrease in adsorbed HSA was signfiicant for coating solutions with serum concentrations of $0.01 \%-1 \%$. On TCPS pretreated with $10 \%$ and $20 \%$ human serum, a decrease in the amount of adsorbed HSA could not be detected by means of the enzyme-immunoassay. During the experiments cell adhesion and spreading was studied by light microscopy. Although cell spreading was most prominent on TCPS pretreated with the highest concentrations of human serum, all surfaces were almost completely covered with spread cells.

In order to confirm a decrease in the amount of adsorbed HSA, during endothelial cell adhesion and spreading on TCPS which had been pre-exposed to serum-containing medium, experiments were also carried out in which ${ }^{131}$ I-labelled HSA was added as tracer protein to these serum solutions. The concentrations of human serum were taken as $1 \%$ and $20 \%$. 

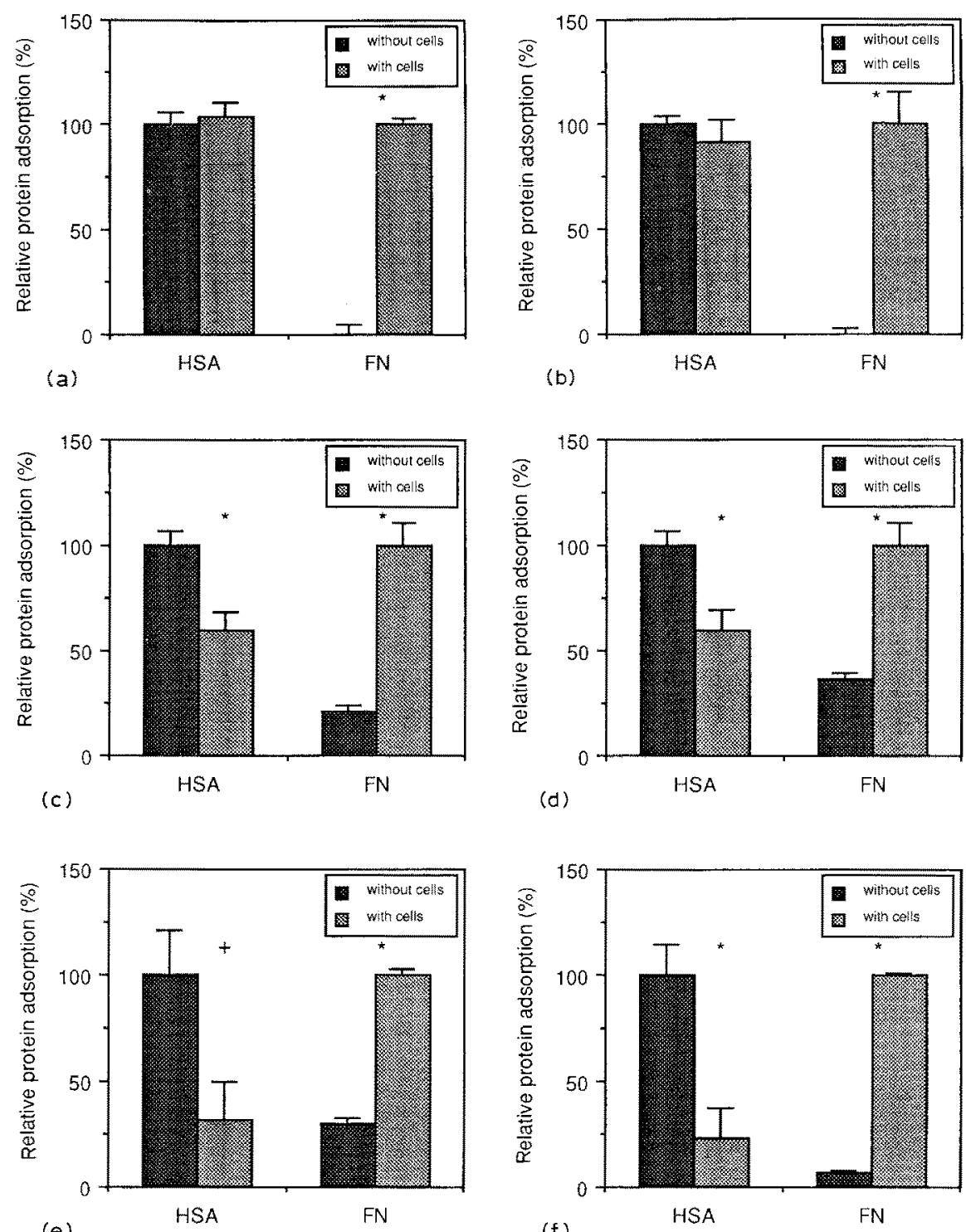

Figure 1 Relative amounts of adsorbed human serum albumin (HSA) and fibronectin (FN) to TCPS, which was exposed to solutions of various concentrations of human serum for $1 \mathrm{~h}$, followed by incubation for $6 \mathrm{~h}$ with serum-free culture medium either with endothelial cells $\left(200000 \mathrm{~cm}^{-2}\right)$ or without cells. Detection: enzyme-immunoassay. In each experiment in which TCPS was exposed to a particular serum concentration, the amount of HSA adsorbed after incubation with medium without cells was taken as $100 \%$, whereas the amount of adsorbed fibronectin was calculated as the percentage of the amount adsorbed after incubation with medium-containing cells. Values are means of four determinations $( \pm$ S.D.). Unpaired $t$-test: $(*) p<0.0005 ;(+) p<0.005$; compared to protein adsorption after incubation with medium without cells (a) $20 \%$ serum, (b) $10 \%$ serum, (c) $1 \%$ serum, (d) $0.1 \%$ serum, (e) $0.05 \%$ serum, (f) $0.01 \%$ serum.

Both on TCPS pretreated with $1 \%$ and with $20 \%$ human serum, significantly less HSA was detected after incubation with a suspension of endothelial cells compared to incubation with serum-free medium without cells (Fig. 2).

\subsection{Fibronectin depostion on to TCPS, TCPET, PET and FEP}

Deposition of fibronectin by endothelial cells suspended in $20 \%$ human serum-containing medium only occurred on to TCPS and TCPET, but not on to PET and FEP (Fig. 3). The results depicted in Fig. 3 show that no fibronectin had been deposited by endothelial cells adhering to PET or FEP during $6 \mathrm{~h}$ incubation. Cells adhering to TCPET and TCPS clearly deposited fibronectin on to these surfaces during this period. Light microscopic observations re- vealed that cells adhered and spread well on both TCPS and TCPET. Cells also adhered and spread on PET, but to a lesser extent than on TCPS, and after $6 \mathrm{~h}$ incubation part of the cells detached from this surface. Cells hardly adhered and spread on FEP.

\subsection{Cell adhesion}

Because the adsorption and desorption behaviour of proteins is different for hydrophobic surfaces compared to hydrophilic surfaces, adhesion of endothelial cells on to FEP, PET (both hydrophobic surfaces) and TCPET as well as TCPS (both relatively hydrophilic surfaces) was studied. These polymers were either exposed or not exposed to $20 \%$ human serum for $1 \mathrm{~h}$ before cells were introduced into the wells.

Pretreatment of FEP and PET with 20\% human serum resulted in a considerably decreased adhesion 


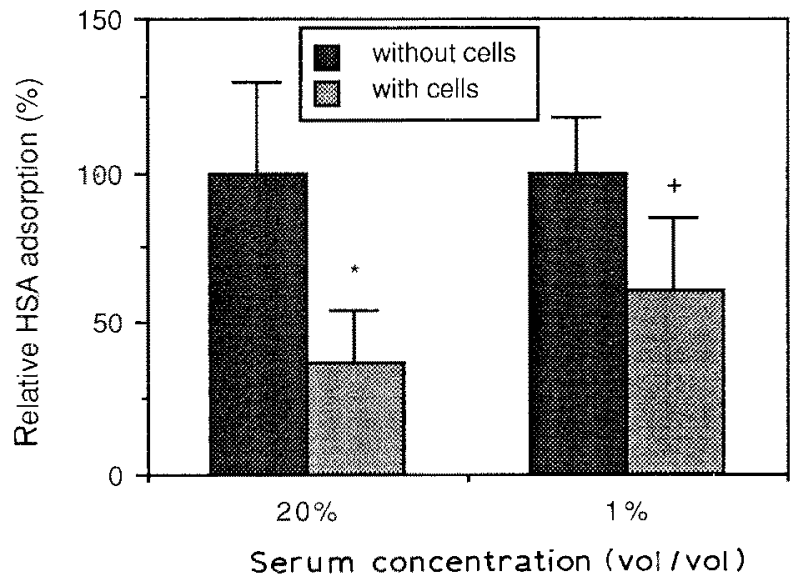

Figure 2 Amounts of adsorbed human serum albumin (HSA) to TCPS, exposed for $1 \mathrm{~h}$ to either $20 \%$ or $1 \%$ human serum, both supplemented with ${ }^{131}$ I-labelled human serum alubin, followed by incubation for $6 \mathrm{~h}$ with serum-free culture medium either with endothelial cells $\left(200000 \mathrm{~cm}^{-2}\right)$ or without cells. ${ }^{13}$ I-labelled human serum albumin was added to the serum solutions to a final concentration of $0.12 \%(\mathrm{wt} / \mathrm{wt})$ of the native HSA present. In each experiment in which TCPS was exposed to a particular serum concentration, the amount of HSA adsorbed after incubation with medium without cells was taken as $100 \%( \pm$ S.D.; $n=4)$. Unpaired $t$-test: $(*) p<0.01 ;(+) p<0.025$ compared to HSA adsorption after incubation with medium without cells.

of endothelial cells (suspended in serum-free medium) after incubation for $6 \mathrm{~h}$ compared to cell adhesion on to the untreated surfaces (Fig. 4). No difference between adhesion of endothelial cells on to untreated and serum-treated TCPET was observed. Cell adhesion on to TCPS was only slightly decreased after the surface was pretreated with $20 \%$ human serum. Spreading of the cells was not optimal on uncoated FEP and PET, but a worse spreading occurred on serum-treated FEP and PET and detachment of cells was observed. Good cell spreading was found on untreated and serum-treated TCPET and TCPS.

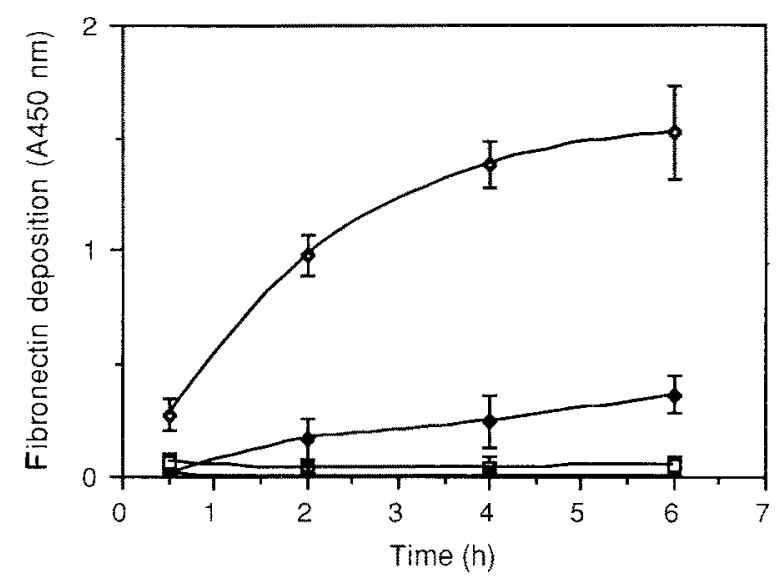

Figure 3 Deposition of fibronectin by human endothelial cells as a function of time during adhesion on to ( $\diamond)$ TCPS, $(\bullet)$ TCPET, (a) PET and ( $\square$ ) FEP. The polymers surfaces were exposed to $20 \%$ human serum-containing culture medium either with endothelial cells $\left(60000 \mathrm{~cm}^{-2}\right)$ or without cells. Fibronectin adsorption values are the differences between the adsorbances of the dye solutions from wells incubated with medium containing cells and medium without cells. Values are means of five determinations ( \pm s.D.).

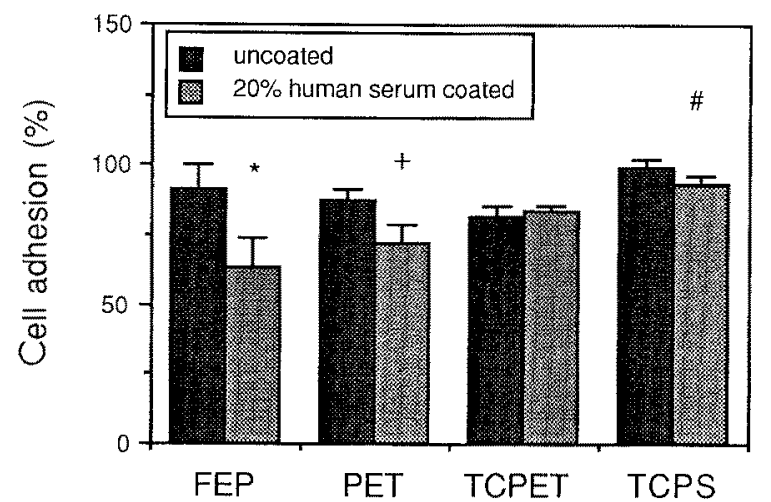

Figure 4 Adhesion of human endothelial cells on to FEP, PET, TCPET and TCPS, which were exposed for $1 \mathrm{~h}$ either to $20 \%$ human serum or to PBS (uncoated). Adhesion of endothelial cells, suspended in serum-free medium, was determined after incubation for $6 \mathrm{~h}$. Adhesion is expressed as percentage of the number of cells adhering to TCPS coated with partially purified fibronectin (reference surface). Values are means of four determinations $( \pm$ S.D.). Unpaired $i$-test: $(*) p<0.005 ;(+) p<0.01 ;(\#) p<0.025$; compared to cell adhesion to uncoated surfaces.

\section{Discussion}

There is evidence that the patency of vascular grafts with a relatively small diameter can probably be improved by an endothelial lining of the luminal surface $[4,5]$. Optimal interaction of the endothelial cells with the graft surface is important for survival of the cell lining after restoration of the blood flow. The present study was undertaken to gain more insight into this interaction, especially in the role of protein adsorption during adhesion of endothelial cells on to polymeric surfaces. Several authors $[3,10,11,22-24]$ have postulated that the deposition of fibronectin by endothelial cells during their adhesion and spreading on TCPS is accompanied by displacement of proteins which had been previously adsorbed to the surface from the serum-containing culture medium. When such displacement is not possible fibronectin deposition will be inhibited and consequently cell adhesion is impaired.

In order to test the above-mentioned hypothesis, the amounts of adsorbed fibronectin and human serum albumin on serum-pretreated TCPS surfaces were determined after incubation for $6 \mathrm{~h}$ with endothelial cells suspended in serum-free medium as well as after incubation with serum-free medium without cells. For detection of the amounts of adsorbed HSA with the enzyme-immunoassay, TCPS was preexposed to $20 \%$ human serum-containing medium as well as to solutions of lower serum concentrations, because earlier experiments revealed that the enzymeimmunoassay employed by us is not suitable to detect relatively small changes in the amount of an adsorbed protein, if a relatively large amount of such a protein has been adsorbed [11]. It has been suggested that in this immunoassay a compact monolayer of antibody molecules, instead of a compact monolayer of (pre)adsorbed protein, determines the maximal amount of adsorbed protein which can be measured [11]. Therefore, the measurement of differences between the amounts of an adsorbed protein is presumably not 
possible when these amounts are large. As a consequence, a decrease in the amount of a preadsorbed protein will not be detected if this amount is not very much reduced during exposure to the cell suspension [11]. By decreasing the serum concentration in the solutions used for pretreatment of the polymer surfaces, the amounts of adsorbed proteins are generally smaller [10]. Consequently, the endothelial cells had to be suspended in medium lacking serum to avoid adsorption of large amounts of serum proteins. In this way it could be shown that the amounts of HSA, preadsorbed to TCPS from serum solutions, decreased during incubation with endothelial cells.

The experiments with respect to the displacement of HSA by cellular fibronectin showed that adhesion and spreading of endothelial cells on TCPS resulted in the deposition of relatively large amounts of cellular fibronectin, irrespective of the serum concentration in the solution used during pretreatment. This shows that there is not a pronounced effect of the amount of already adsorbed serum fibronectin on the deposition of cellular fibronectin. Although the amounts of adsorbed serum fibronectin from experiments in which different serum concentrations were used, may not quantitatively be compared, the results suggest an optimum in fibronectin adsorption from serum solutions to TCPS (not exposed to cell suspensions afterwards) at about $0.1 \%$ serum. This is in agreement with the results of other authors $[10,24]$. The amounts of HSA adsorbed to TCPS, which had been pretreated with solutions with serum concentrations ranging from $0.01 \%-1 \%$, were significantly less after incubation with cells in culture medium compared to incubation with medium without cells. Because endothelial cells deposit relatively large amounts of fibronectin on to TCPS, the most plausible explanation for the decrease in the amount of adsorbed HSA is, that previously adsorbed HSA had been displaced by cellular fibronectin.

The decrease in the amount of adsorbed HSA during incubation with a cell suspension, was confirmed by adding ${ }^{131} \mathrm{I}$-labelled $\mathrm{HSA}$ as tracer protein to human serum solutions used for pretreatment of the TCPS surfaces. In this way, a decrease in the amount of adsorbed HSA was not only found when TCPS had been pretreated with $1 \%$ human serum, but also when $20 \%$ serum was used. The trace labelling experiment in which $1 \%$ human serum was used for pretreatment of TCPS rules out the possibility that the decrease in HSA adsorption after incubation with cells, as detected by the enzyme-immunoassay, was caused by masking of preadsorbed HSA molecules by fibronectin or by any mechanism other than desorption of HSA from the TCPS surface. Furthermore, the trace labelling experiment confirms our supposition that the enzyme-immunoassay is not suited to detect relatively small changes in the amount of adsorbed protein, when large amounts of protein are adsorbed.

Although the mechanism of displacement of adsorbed serum proteins by cellular fibronectin has only been demonstrated for endothelial cells seeded from serum-free medium, it is plausible that this mechanism also applies for cells seeded from $20 \%$ human serum- containing culture medium, because fibronectin deposition by cells suspended in serum-free medium as a function of time is almost equal to fibronectin deposition by cells suspended in $20 \%$ serum-containing medium (data not shown). Moreover, the experiments in which fibronectin depositions on to TCPS, TCPET, PET and FEP were compared, showed that a relatively large amount of fibronectin was deposited on to TCPS after incubation for $6 \mathrm{~h}$ with endothelial cells suspended in $20 \%$ serum-containing culture medium (Fig. 3). This was also the case in the protein displacement experiments (Fig. 1).

Besides fibronectin, human endothelial cells also produce other adhesive proteins, such as laminin, elastin, collagens and von Willebrand factor $[25,26]$. It is possible that these proteins may cooperate in the desorption of HSA. However, this does not alter the hypothesis that adhesive proteins secreted by human endothelial cells displace adsorbed serum proteins during the in vitro adhesion and spreading of these cells.

Former experiments in our laboratory concerning the adhesion of human endothelial cells on to polymeric surfaces, revealed that these cells hardly adhere and spread on hydrophobic polymers [3]. The polymers used for vascular grafts, Dacron (PET) and Teflon (polytetrafluoroethylene), are hydrophobic. It is generally accepted that proteins are less reversibly adsorbed to hydrophobic surfaces compared to hydrophilic surfaces $[15,16]$. Therefore, displacement of adsorbed serum proteins by cellular proteins will be more difficult in the case of a hydrophobic surface compared to a hydrophilic surface.

Two hydrophobic polymers, PET and FEP, as well as two polymer surfaces, TCPS and TCPET, which are more hydrophilic [3], were compared with respect to cell adhesion and fibronectin deposition. The supposition, that the poor desorption of adsorbed serum proteins from hydrophobic surfaces inhibits fibronectin deposition, and as a consequence cell adhesion and spreading, was confirmed by the results of the fibronectin deposition experiments (Fig. 3) as well as the cell adhesion studies (Fig. 4). Deposition of fibronectin by endothelial cells, resuspended in $20 \%$ serum-containing medium, to FEP and PET was found to be absent, even though a substantial number of cells adhered to PET. Adhesion of endothelial cells on to the hydrophobic PET and FEP, which were preexposed to $20 \%$ human serum, was considerably impaired compared to PET and FEP surfaces which were not pre-exposed to serum-containing medium. On the contrary, endothelial cell adhesion was almost identical to the serum-pretreated and untreated polymers surfaces TCPS and TCPET, which are more hydrophilic. Evidently, exposure of the hydrophobic PET and FEP to a serum solution results in the irreversible adsorption of proteins, and displacement of these proteins by cellular fibronectin does not occur. As a consequence, endothelial cell adhesion and spreading is impaired. Results from the literature also confirm the mentioned hypothesis. Van Wachem et al. [10] showed that precoating of TCPS with highdensity lipoprotein, immunoglobulin G or HSA only 
resulted in a delay of endothelial cell adhesion compared to cell adhesion on to uncoated TCPS during $6 \mathrm{~h}$ incubation with a suspension of cells in serumcontaining medium. On the contrary, cell adhesion on to PET and FEP, precoated with the same proteins, was totally inhibited. These results suggest that the preadsorbed proteins, which inhibit cell adhesion, were displaced from TCPS by cellular fibronectin while displacement of proteins from the more hydrophobic PET and FEP surfaces did not occur [23]. Moreover, they found that adherent endothelial cells hardly spread on uncoated PET, when the cells were seeded from $20 \%$ human serum-containing culture medium. However, on uncoated PET cell spreading was almost the same as on TCPET, if the uncoated PET surfaces were incubated for $30 \mathrm{~min}$ with endothelial cells suspended in serum-free medium, after which the supernatant was replaced by serumcontaining culture medium [27]. In the latter case, endothelial cells had probably deposited cellular fibronectin before serum proteins could adsorb to the surface.

In conclusion, human endothelial cells can only deposit fibronectin during adhesion and spreading on polymer surfaces if serum proteins which are already adsorbed, can be displaced by cellular fibronectin. Such a displacement is possible in the case of moderately water-wettable polymeric surfaces, and these surfaces show a good adhesion and spreading of cells. In vitro, endothelial cells fail to adhere and spread on hydrophobic polymers, like the vascular graft materials Dacron and Teflon. This is most probably due to the fact that adsorbed serum proteins cannot be displaced by cellular fibronectin. In order to optimize adhesion of human endothelial cells on to vascular grafts, the luminal surface has to be modified in such a way that displacement of adsorbed proteins by cellular fibronectin is possible.

\section{Acknowledgements}

We thank Drs G. van der Sluijs Veer and I. Vermes, the hospital "Medisch Spectrum Twente", Enschede, The Netherlands, for their support, and the obstetric staff of this hospital for the supply of umbilical cords.

\section{References}

1. L. M. GRAHAM and J. J. BERGAN, in "Biological and Synthetic Vascular Prostheses", edited by J. C. Stanley, W. E. Burkel, S. M. Lindenauer, R. H. Bartlett and J. G. Turcotte (Grune and Stratton, New York, 1982) p. 563.

2. B. E. JARRELL, S. K. WILLIAMS, L. SOLOMON, L. SPEICHER, E. KOOLPE, J, RADOMSKI, R. A. CAR ABASI, D. GREENER and F. E. ROSATO, Ann. Surg. 203 (1986) 671.

3. P. B. van WACHEM, T, BEUGELING, J. FEIJEN, A. BANTJES, J. P. DETMERS and W. G. van AKEN, Biomater. 6 (1985) 403

4. M. B. HERRING, in "Vascular Grafting, Clinical Applications and Techniques", edited by C. B. Wright (John Wright PSG, Boston, 1983) p. 27.
5. J. C. STANLEY, W, E. BURKEL, L. M. GRAHAM and B. LINDBLAD, Acta Chir. Scand. Suppl. 529 (1985) 17.

6. M. HERRING, A. GARDNER and J. GLOVER, ASAIO J.8 (1985) 74.

7. P. ÖRTENWALL, H. WADENVIK, J. KUTTI and B. RISBERG, J. Vasc. Surg, 6 (1987) 17.

8. K. BERGER, L. R. SAUVAGE, A. M. RAO and S. J WOOD, Ann. Surg. 175 (1972) 118.

9. J. M. ANDERSON, M. F. ABBUHL, T. HERING and K. H. JOHNSTON, ASAIO J.8 (1985) 79.

10. P. B. van WACHEM, C. M. VRERIKS, T. BEUGELING, J. FEIJEN, A. BANTJES, J. P. DETMERS and W. G. Van AKEN, J Biomed. Mater. Res. 21 (1987) 701.

11. P. B, van WACHEM, B. W, L. MALLENS, A DEKKER, T. BEUGELING, I. FEIJEN, A, BANTJES, J. P. DETMERS and W. G. van AKEN, ibid. 21 (1987) 1317.

12. T. SATO, K. ARAI, S. ISHIHARAJIMA and G. ASANO, Exp. Molec. Path. 47 (1987) 202.

13. I. GIAEVER and C. R. KEESE, in: ACS Symposium Series 343 Edited by J. L. Brash and T. A. Horbett (American Chemical Society, Washington DC, 1987) p. 582.

14. C. PUSINERI and J. P. CAZENAVE, in "Blood-surface interactions. Biological principles underlying hemocompatibility with artificial materials", edited by J. P. Cazenave, J. A. Davies, M. D. Kazatchkine and W. G, van Aken (Elsevier, Amsterdam, 1986) p. 261.

15. J. FEIJEN, T. BEUGELING, A. BANTJES and C. Th SMi I SIBINGA, in "Advances in cardiovascular physics", Vol. 3, edited by D. N. Ghista (S. Karger; Basel, 1979) p. 100.

16. J. L. BRASH, in "Biocompatible polymers, metals and composites", edited by M. Szycher (Technomic, Lancaster, USA, 1983) p. 35.

17. A. POOT, BEUGELING, W. G. van AKEN and A. BANTJES, J. Biomed. Mater. Res. 24 (1990) 1024

18. Ch. WILLEMS, G. C. B. ASTALDI, Ph. D. DE GROOT, M. C. JANSEN, M. D. GONSALVES, W. P. ZEIJLEMAKER, J. A. van MOURIK and W. G, van AKEN, Exp. Cell. Res. 139 (1982) 191

19. P. B. van WACHEM. J. H. REINDERS, M. F. van BUULWORTELBOER, Ph. G. de GROOT, W. G. van AKEN and J. A. van MOURIK, Thromb. Haemost. 56 (1986) 189.

20. D. C. WEST, A. SATTAR and S. KUMAR, Anal. Biochem. $147(1985) 289$.

21. G. MATES, M. DANIEL and C. WALKER, Cell Biol. Intern. Rep. $10(1986) 641$

22. T. BEUGELING, A. POOT, P. B. van WACHEM, E. BRINKMAN, W. G. van AKEN and A. BANTIES, in "Proceedings of the Vth International Conference on Poly. mers in Medicine and Surgery", Leeuwenhorst Congress Center, Holland, September 1986, p. 36/1.

23. P. B. van WACHEM, T. BEUGELING, B. W. L. MALLENS, A. DEKKER, J. FEIJEN, A. BANTJES and W. G. van AKEN, Biomater. $9(1988) 121$

24. F. GRINNELL and M. K. FELD, J. Biol. Chem. 257 (1982) 4888 .

25. H. SAGE, in "Vascular endothelium in hemostasis and thrombosis", edited by M. A. Gimbrone (Churchill Livingstone, Edinburgh, 1986) p. 187.

26. J. H. REINDERS, Ph. G. de GROOT, M. D. GONSALVES, J. ZANDBERGEN, C. LOESBERG and J. A. van MOURIK, Biochim. Biophys. Acta 804 (1984) 361.

27. P. B. van WACHEM, J. M. SCHAKENRAAD, J. FEIJEN, T. BEUGELING, W. G. van AKEN, E. H. BLAAUW, P. NIEUWENHUIS and 1. MOLENAAR, Biomater. 10 (1989) 532

Received 16 November 1990

and accepted 8 April 1991 